sodium into the cells. However, no excess of exchangeable sodium has been shown, even though an expanded extracellular auid volume was found. When exchangeable sodium has been found to be increased (Oleson, 1964), the excess has been wolly accounted for by the increase in extracellular fluid sodium. Calculation of the residual sodium in our patients shows little increase and provides further evidence against the hypothesis that sodium has entered the cells. The methods used are likely to overestimate the residual sodium, since transcellular water, a term introduced to describe water in glandular lumina and cerebrospinal fluid (Edelman, Olney, James, Brooks, and Moore, 1952), appears to be penetrated less by sulphate than by sodium. For example, equilibration of sulphate with ine cerebrospinal fluid is slow and incomplete (Richmond and Hastings, 1960), whereas $90 \%$ of the cerebrospinal fluid ezchanges with ${ }^{24} \mathrm{Na}$ at 24 hours (Miller and Wilson, 1953). The findings therefore indicate that the measured depletion of total exchangeable potassium is mainly a reflection of loss of cell mass. It appears that there is a reduction in the intracellular water, since extracellular fluid volume is increased, shile the total body water expressed as a percentage of body welght is normal.

The close correlation between potassium depletion and welght deficit (Fig. 3) indicates the importance of loss of weight in producing this depletion.

Measurements of intracellular electrolyte concentration are difficult, though the problem for potassium is less than for sodium, since the extracellular content is small. Flear, Crampton, and Matthews (1961) found no change in the intracellular potassium content of skeletal muscle in patients with congestive heart failure, using an in-vitro inulin method for the determination of the extracellular space. It is probable, however, that a slight fall in intracellular potassium concentration occurs when there is hyponatraemia, since a fall in the plasma sodium concentration is balanced by a corresponding fall in the concentration of the principal intracellular cation.

If the myocardial cells are affected in the same ways as the rest of the body, a lowered intracellular potassium concentration $[\mathrm{K}]_{1}$ would be expected to lower the membrane potential $\mathrm{E}$, according to the Nernst equation $\left(E \propto \log \frac{\left[K_{i}\right]}{\left[K_{e}\right]}\right)$, where $\left[K_{e}\right]$ is the extracellular potassium concentration, and thus to increase the excitability of the cell and produce arrhythmias. Only 6 of the 28 patients who had operations had ventricular arrhythmias in the immediate postoperative period. There was no relation between the incidence of arrhythmias and the extent of potassium depletion.

Patients with severe heart disease could not be maintained free of oedema without diuretic therapy, and this treatment has in the past been incriminated as the cause of low body potassium (Lockey et al., 1966). The four patients not on diuretic therapy all had low levels of body potassium, though the depletion was slightly less than in those on treatment, probably because their heart disease was less severe; these particular patients had no weight deficiency. Our evidence therefore indicates that diuretic treatment has little direct part in producing potassium depletion.

It seems that the reduction in cell mass is the major factor involved in decreasing the exchangeable potassium, and that no significant fall in intracellular potassium occurs.

\section{REFERENCES}

Alkawa, J. K., and Fitz, R. H. (1955). Circulation, 12, 897.

Beilin, L. J., Knight, G. J., Munro-Faure, A. D., and Anderson, J. (1966). fournal of Clinical Investigation, 45, 1817.

Birkenfeld, L. W., Liebman, J., O'Meara, M. P., and Edelman, I. S. (1958). Fournal of Clinical Investigation, 37, 687.

Carroll, H. J., Gotterer, R., and Altshuler, B. (1965). Circulation, 32, 185.

Crooks, J., Bluhm, M. M., and Muldowney, F. P. (1959). Clinical Science, 18, 175.

Edelman, I. S., Olney, J. M., James, A. H., Brooks, L., and Moore, F. D. (1952). Science, 115, 447.

Farber, S. J., and Soberman, R. J. (1956). Fournal of Clinical Investigation, 35, 779.

Flear, C. T. G., Crampton, R. F., and Matthews, D. M. (1961). Clinical Science, $21,381$.

Flear, C. T. G., Quinton, A., Carpenter, R. G., Domenet, J. G., and Sivyer, A. (1966). Clinica Chimica Acta, 13, 1.

Lockey, E., Longmore, D. B., Ross, D. N., and Sturridge, M. F. (1966). Lancet, 1, 671 .

MacGillivray, I., Buchanan, T. J., and Billewicz, W. Z. (1960). Clinical Science, 19,17

McMurrey, J. D., et al. (1958). Metabolism, 7, 651.

Miller, H., and Wilson, G. M. (1953). Clinical Science, 12, 97.

Oleson, K. H. (1964). Acta Medica Scandinavica, 175, 301.

Oleson, K. H. (1966). Circulation, 34, 322.

Oleson, K. H. (1967). Circulation, 35, 895.

Richmond, J. E., Hastings, A. B. (1960). American fournal of Physio$\log y, 199,814$.

Savoie, J. C., and Jungers, P. (1965). Revue Française d'Études Cliniques et Biologiques, 10, 99 . Swan, R. C., Feinstein, H. M., and Madisso, H. (1956). fournal of
Clinical Investigation, 35, 607.

\title{
Cardiac Abnormalities in Poisoning with Tricyclic Antidepressants
}

\author{
J. W. FREEMAN,* M.B., B.S., M.R.A.C.P. ; G. R. MUNDY, $\dagger$ MB., B.S. \\ R. R. BEATTIE, $\ddagger$ M.B., B.S. ; C. RYAN, $\dagger$ M.B., B.S.
}

British Medical fournal, 1969, 2, 610-611

\footnotetext{
Summary : Of $B O$ consecutive admissions to a general hospital for drug overdose, 10 had taken one or other of the ricyclic antidepressants. All 10 had bnormalities of cardiac conduction as shown by prolonged $Q-T_{e}$ intervals, and eight had $S-T$ segment and $T$-wave changes. Five of the 10 patients had arrhythmias and two of those died. Continuous electrocardiographic monitoring is recommended in patients with overdosage of tricyclic antidepressants.
}

\section{Introduction}

The iminodibenzyl derivatives, imipramine and amitriptyline, also known as the tricyclic compounds, may produce alterations in myocardial conduction, cardiac arrhythmias, and death when taken in excessive doses (Connelly and Venables, 1961;

- Resuscitation Officer.

+ Senior Resident Medical Officer.

$\mp$ Medical Registrar.

₹ Medical Registrar.
Royal Hobart Hospital, Hobart, Tasmania 7000. 
Sunshine and Yaffe, 1963 ; Nicholls, 1965 ; Ramsay, 1967 ; Barnes et al., 1968). These effects of the drugs, and the increasing frequency of their use in suicidal attempts, have complicated the management of patients with drug overdoses, whether or not they are known to have taken one of the tricyclic compounds.

\section{Patients and Observations}

All patients admitted to this hospital since April 1968 with the diagnosis of drug overdose have been included in a prospective survey. Ten of the 80 patients admitted in the succeeding six months are known to have taken one of the tricyclic compounds, either amitriptyline (Tryptizol), nortriptyline (Aventyl), imipramine (Tofranil), or desipramine (Pertofran). Abnormalities have been observed in the electrocardiograms (E.C.G.) of these 10 patients. All were under 60 years of age ; eight were under 40 years of age; and eight were women. Two of the 10 patients died and their case records are described in detail.

\section{E.C.G. Abnormalities}

Alterations in $Q-T_{c} .-$ The corrected $\mathrm{Q}-\mathrm{T}$ interval $\left(\mathrm{Q}-\mathrm{T}_{\mathrm{c}}\right)$ was prolonged in all 10 patients, the upper limit of normal being taken as $0.42 \mathrm{sec}$. in men and $0.43 \mathrm{sec}$. in women (Goldman, 1967). In five patients the $\mathrm{Q}-\mathrm{T}_{\mathrm{c}}$ was between 0.45 and $0.5 \mathrm{sec}$. and in five patients it was over $0.5 \mathrm{sec}$. Serial E.C.G.s in four patients showed the time taken for the Q-T. to revert to normal varied from 36 to 96 hours.

S-T Segment Depression.- This was found in eight patients. Serial E.C.G.s in four patients showed that these changes reverted to normal in from 36 hours to seven days.

Arrhythmias.-One patient, a 37-year-old man with no previous history of heart disease, showed rapid atrial fibrillation on admission which reverted to sinus rhythm in 24 hours. Two other patients had definite sinus tachycardia with heart rates greater than $130 / \mathrm{min}$. Multiple arrhythmias were also seen in the two fatal cases.

\section{Case 1}

A woman aged 32 was admitted to hospital three hours after the ingestion of an unknown amount of amitriptyline, nortriptyline, and diazepam. She was deeply unconscious and did not react to painful stimuli; her blood pressure was $120 / 80 \mathrm{~mm}$. $\mathrm{Hg}$ and pulse rate $84 / \mathrm{min}$. She was treated with intermittent positive-pressure respiration and mannitol to induce a forced diuresis, but her blood pressure fell to $80 / 60 \mathrm{~mm}$. $\mathrm{Hg}$ six hours after admission and a metaraminol infusion was begun. An E.C.G. 18 hours after admission showed nodal rhythm with prolongation of the QRS time $(0 \cdot 16 \mathrm{sec}$ ) and gross $\mathrm{S}-\mathrm{T}$ segment and $\mathrm{T}$-wave changes. Serum electrolytes and acid-base status were normal. Serial E.C.G.s showed a return to sinus rhythm and shortening of the QRS time to $0.12 \mathrm{sec}$. over the next 12 hours. She died 40 hours after admission.

\section{Case 2}

A woman aged 27 was admitted to hospital half an hour after taking an unknown quantity of desipramine and thioridazine. She was conscious but drowsy; however, four hours later she collapsed, her blood pressure fell to $120 / 80 \mathrm{~mm}$. $\mathrm{Hg}$, and her pulse was rapid and irregular. An E,C.G. showed bursts of ventricular fibrillation and ventricular flutter, a variable prolongation of the QRS time up to $0.16 \mathrm{sec}$., and a second-stage atrioventricular block.

After starting intermittent positive-pressure respiration, intravenous lignocaine $100 \mathrm{mg}$. and intravenous phenytoin $250 \mathrm{mg}$. produced no change in the rhythm or conduction patterns, though both are known to have a beneficial effect on ventricular arrhythmias. Stable atrial fibrillation with a ventricular rate of $70 / \mathrm{min}$. was produced after propranolol $18 \mathrm{mg}$. had been given intravenously in increments; however, gross abnormalities persisted in the $S-T$ segments and $T$ waves. During this time her general condition deteriorated, though a high urinary output continued for the next three hours. Gross hypernatraemia and hypokalaemia persisted throughout her illness. The former appeared to be due to cerebral causes, as the serum sodium did not fall in response to the intra- venous infusion of large amounts of $5 \%$ dextrose. Her urinary output remained high, but the sodium content was consistently less than $15 \mathrm{mEq} / \mathrm{l}$. The blood pressure was maintained with isoprenaline and metaraminol for three days, after which it remained stable at $120 / 90 \mathrm{~mm}$. $\mathrm{Hg}$. An electroencephalogram on the fourth day showed an equipotential tracing with no evidence of cerebral activity. Six days after admission her pulse and blood pressure suddenly dropped and an E.C.G. revealed idioventricular rhythm, which progressed to asystole despite attempts at resuscitation.

\section{Discussion}

The increasing use of the tricyclic compounds in the treatment of depression has led to an increase in their use in suicide attempts. Reports of arrhythmias and conduction defects after overdoses of these compounds have appeared, but the frequency of conduction defects as shown by prolonged $\mathrm{Q}-\mathrm{T}_{\mathrm{c}}$ intervals, and the $S-T$ segment and $T$-wave changes have not been described before. Electrocardiographic abnormalities, however, have been observed in patients taking therapeutic doses of the tricyclic compounds (Alps et al., 1968) and in those taking overdoses (Steel et al., 1967).

The mode of death has often been obscure, but has probably been related to cardiac arrhythmias. The only suggested successful method of treatment of the arrhythmias is the use of pyridostigmine (Rasmussen, 1965), since the tricyclic compounds act as anticholinergic agents (Goodman and Gilman, 1965). Sigg et al. (1963) have shown that low doses of the tricyclic, compounds cause sensitization of adrenergic receptors, while higher doses reduce the cardiac output. The use of the $\beta$-adrenergic blocking agent propranolol in the treatment of arrhythmias caused by these compounds has been suggested (Stannard and Caplan, 1967), and in our second case both the ventricular arrhythmias and prolongation of the QRS time were abolished within five minutes of the drug being given, though gross $\mathrm{S}-\mathrm{T}$ segment and $\mathrm{T}$-wave changes persisted. Propranolol, however, slowed the heart rate and probably together with its negative inotropic effect contributed to the patient's hypotension. In retrospect, it may have been advisable to have given atropine intravenously as well, and to have used a $\beta$-adrenergic blocking agent without negative inotropic effects such as D-propranolol (Howitt et al., 1968) or I.C.I. 50172 (Gibson and Sowton, 1968).

Hence it appears that any patient who has taken an overdose of one of these drugs is at risk. The difficulty in obtaining a reliable history from these patients, and the fact that their clinical condition may deteriorate rapidly, as in our second case, suggest that continuous monitoring of the E.C.G. is highly desirable.

We are grateful to Professor A. G. Baikie for permission to report Case 1 and for his help and advice in the preparation of this paper. We also wish to thank Dr. R. A, Pargiter and Dr. C. I. A. Williams for permission to report details of patients under their care.

\section{REFERENCES}

Alps, B. J., Harry, T. V. A., and Wilson, A. B. (1968). British Medical

fournal, 3, 743.
Barnes, R. J., Kong, S. M., and Wu, R. W. Y. (1968). British Medical fournal, 3, 222.

Connelly, J. F., and Venables, A. W. (1961). Medical fournal of Australia, 1, 108.

Gibson, D., and Sowton, E. (1968). British Medical fournal, 1, 213.

Gibson, D., and Sowton, E. (1968). British Medical fournal, 1, 213. ed., p. 28. Los Altos, Lange.

Goodman, L. S., and Gilman, A. (1965). The Pharmacological Basis of Therapeutics, 3rd ed., p. 200. New York, Macmillan.

Howitt, G., Rowlands, D. J., Leung, D. Y. T., and Logan, W. F. W. E. (1968). Clinical Science, 34, 485

Nicholls; H. K. M. (1965). New Zealand Medical fournal, 64, 651.

Ramsay, I. D. (1967). Lancet, 2, 1308.

Sigg, E. B., Osborne, M., and Korol, B. (1963). Fournal of Pharmacology and Experimental Therapeutics, 141, 237.

Stannard, M., and Caplan, H. L. (1967). Medical fournal of Australia, 2,

22. Steel, C. M., O'Duffy, J., and Brown, S. S. (1967). British Medical fournal, 3, 663 .

Sunshine, P., and Yaffe, S. J. (1963). American fournal of Diseases of Children, 106, 501. 